\title{
Effects of Glucose on the Reactive Black 5 (RB5) Decolorization by Two White Rot Basidiomycetes
}

\author{
Tony Hadibarata ${ }^{1}{ }^{*}$, Abdull Rahim Mohd Yusoff ${ }^{1}$, Azmi Aris ${ }^{1}$, \\ Risky Ayu Kristanti ${ }^{2}$, Topik Hidayat ${ }^{3,4}$ \& Adhi Yuniarto ${ }^{5}$ \\ ${ }^{1}$ Institute of Environmental and Water Research Management, \\ Universiti Teknologi Malaysia \\ ${ }^{2}$ Dept. of Chemical and Environmental Engineering, Yamanashi University \\ ${ }^{3}$ Dept. of Biological Science Faculty of Bioscience and Bioengineering, \\ Universiti Teknologi Malaysia \\ ${ }^{4}$ Dept. of Biology Education, Faculty of Mathematic and Natural Science, \\ University of Education (UPI) Bandung, Indonesia \\ ${ }^{5}$ Dep. of Environmental Engineering, Institut Teknologi Sepuluh Nopember (ITS) \\ Surabaya, Indonesia \\ Email: hadibarata@utm.my
}

\begin{abstract}
The capacities of glucose in the decolorization process of an azo dye, Reactive Black 5 (RB5), by two white rot basidiomycetes, Pleurotus sp. F019 and Trametes sp. F054 were investigated. The results indicated that the dye degradation by the two fungi was extremely correlated with the presence of glucose in the culture and the process of fungi growth. Decolorization of $200 \mathrm{mg}$ dye $/ 1$ was increased from $62 \%$ and $69 \%$ to $100 \%$ within $20-25 \mathrm{~h}$ with the increase of glucose from 5 to $15 \mathrm{~g} / \mathrm{l}$, and the activity of manganese dependent peroxidase (MnP) increased by 2-9 fold in this case. Hydrogen peroxide of 0.55 $\mathrm{mg} / \mathrm{l}$ and $0.43 \mathrm{mg} / \mathrm{l}$ were detected in $10 \mathrm{~h}$ in Pleurotus sp. F019 and Trametes sp. F054 cultures.
\end{abstract}

Keywords: Decolorization; Glucose; Manganese peroxidase; Pleurotus sp. F019; Reactive Black 5; Trametes sp. F054.

\section{$1 \quad$ Introduction}

Large quantities of dyes are annually produced and implemented in many different industries, such as textiles, pharmaceutical, cosmetics, paper, leather, and food [1]. The major environmental problems as results of large production and usage of dyes have been attracted widespread interests [2]. Reactive dyes, which are the only textile colorants designed to bond covalently with cellulosic fibers, are extensively used in the textile industry because of their large class of color shades, high wet fastness profiles, ease of application, brilliant colors, and minimal energy consumption [3]. Many investigations were focused on the biological methods due to the potentially low cost. Decolorization of various dyes using white rot basidiomycetes or their ligninolytic enzymes were Received February $2^{\text {nd }}, 2011$, Revised April 20 ${ }^{\text {th }}, 2011$ Accepted for publication May $6^{\text {th }}, 2011$.

*Corresponding author: Tony Hadibarata, Institute of Environmental and Water Research Management, Universiti Teknologi Malaysia, 81310 Skudai, Johor, Malaysia. Tel:+607-5531760; Fax: +607-5531760 Copyright @ 2011 Published by LPPM ITB, ISSN: 1978-3043, DOI: 10.5614/itbj.sci.2011.43.3.3 
extensively investigated in recent years and some bioreactors in lab-scale were suggested for this objective [4]. White rot basidiomycetes are the most powerful ligninolytic microorganisms adequate of degrading various forms of dyes such as reactive, azo, heterocyclic and polymeric dyes. This ability is due to extracellular non-specific and non-stereoselective enzyme systems composed of laccases (EC 1.10.3.2), lignin peroxidases (EC 1.11.10.14) and manganese peroxidases (EC 1.11.1.13) [5,6].

\section{$2 \quad$ Materials and Methods}

\subsection{Dye}

Reactive Black 5 (RB5, Color Index) and other chemicals were purchased from Wako Pure Chemical Industry Co. Ltd. (Osaka, Japan) at the highest purity available. The structure of RB5 is shown in Figure 1.

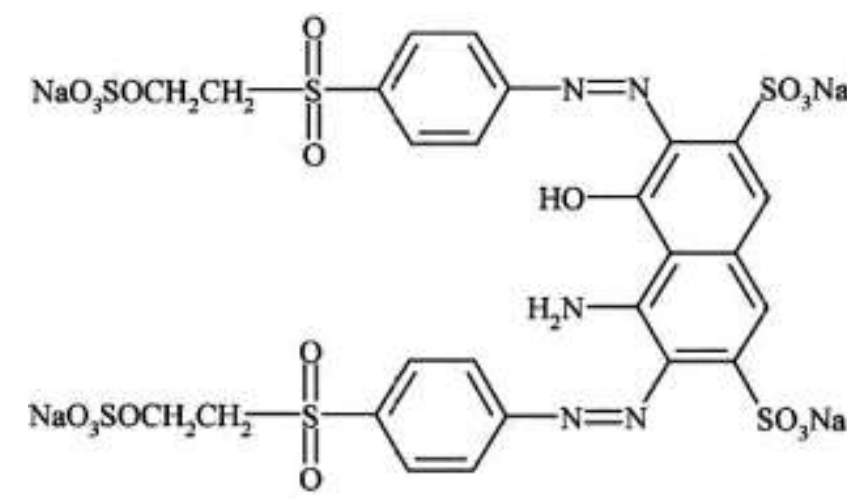

Figure 1 The chemical structures of RB5.

\subsection{Microorganisms and Decolorization Experiments}

Pleurotus sp. F019 and Trametes sp. F054 were isolated from a tropical rain forest in Samarinda, Indonesia and Johor Bahru, Malaysia. The fungi were maintained on malt extracts agar $(2 \%(\mathrm{w} / \mathrm{v})$ malt extract, $2 \%(\mathrm{w} / \mathrm{v})$ glucose, $0.1 \%(\mathrm{w} / \mathrm{v})$ poly peptone, and $1.5 \%(\mathrm{w} / \mathrm{v})$ agar) in a plastic petri dish at $4{ }^{\circ} \mathrm{C}$ prior to use. Experiments were performed by using 100-ml Erlenmeyer flasks and incubated at room condition. Flasks were prepared in triplicates and contained $20 \mathrm{ml}$ nutrient media with RB5. An 5-mm active plug cut from the pure fungal culture grown on agar plates was used for inoculation of flasks under sterile conditions. Control flasks contained only RB5 and nutrients, but no fungi. The cultures were incubated for 6 days at a static place. All of glucose influence were tested with a RB5 concentration of $200 \mathrm{mg} / \mathrm{l}$. Samples (triplicate flasks) were taken periodically, centrifuged at $8000 \mathrm{~g}$ for $20 \mathrm{~min}$ at $15^{\circ} \mathrm{C}$ and the 
clear supernatant obtained was used for determination of decolorization rate spectrophotometrically by reading UV-Vis Spectrophotometer with the absorbance at $\lambda_{\max }(598 \mathrm{~nm})$. The percentage of decolorization was calculated as follow:

$$
\text { Decolorization }(\%)=\left(1-\frac{C}{C_{0}}\right) \times 100
$$

where $\mathrm{C}_{0}$ is initial dye concentration and $\mathrm{C}$ is final dye concentration [7].

\subsection{Assay of Manganese Dependant Peroxidase}

Enzyme activity was determined spectrophotometrically at $25^{\circ} \mathrm{C}$. Manganese peroxidase (MnP) activity was assayed at $468 \mathrm{~nm}$ using dimethoxyphenol (DMP) as the substrate [8]. One unit (U) of enzyme activity was defined as the amount of enzyme required producing one micromole of product per minute.

\subsection{Determination of $\mathrm{H}_{2} \mathrm{O}_{2}$ Concentration}

$\mathrm{H}_{2} \mathrm{O}_{2}$ concentration in the culture was determined by iodometric titration as described by Harris [9].

\section{$3 \quad$ Results and Discussion}

\subsection{Relationship between Glucose Consumption and RB5 Decolorization}

The kinetic process of glucose consumption against cultivation time was detected as shown in Figure 2. Glucose consumption process and dye decolorization by the two basidiomycetes were very similar. Consumption of glucose was occur very fast and expended within $25 \mathrm{~h}$ incubation, which was parallel to the rapid decolorization period on $15 \mathrm{~h}$ of incubation. RB5 was decolorized $98 \%$ and $95 \%$ by Pleurotus sp. F019 and Trametes sp. F054 at the completion of incubation. The decolorization process proceeded into a slow step after $15 \mathrm{~h}$, whereas still high activity of manganese peroxidase in the culture. It is evident that decolorization process during the mechanism of dye decolorization by these two basidiomycetes was highly correlated with the growth of fungi and the presence of glucose in the culture. In the previous studies, the basidiomycetes could not utilize the dye as a sole carbon and energy source for growth of fungi and production of enzyme. Glucose played as a cometabolic substrate for dye decolorization, that was correponding with the results obtained in white rot basidiomycetes by other researcher [10,11]. On the other hand, in most white rot basidiomycetes, glucose or other carbon sources supplied an essential substrate for the production of enzyme and growth of the cell, in which the production of ligninolytic enzyme was performed throughout 
their secondary metabolism and was effected by limited nutrient stage. The process of dye removal was developed after production of the enzyme [12]. The condition in two basidiomycetes was slight different from mainly white rot basidiomycetes, wherein the dye removal development occurred throughout the increase phase of fungal cells and at most under the form of sufficiently nutrients availability. The indication of dye removal by basidiomycetes proposed different side of glucose roles and an unknown mechanism of dye removal.

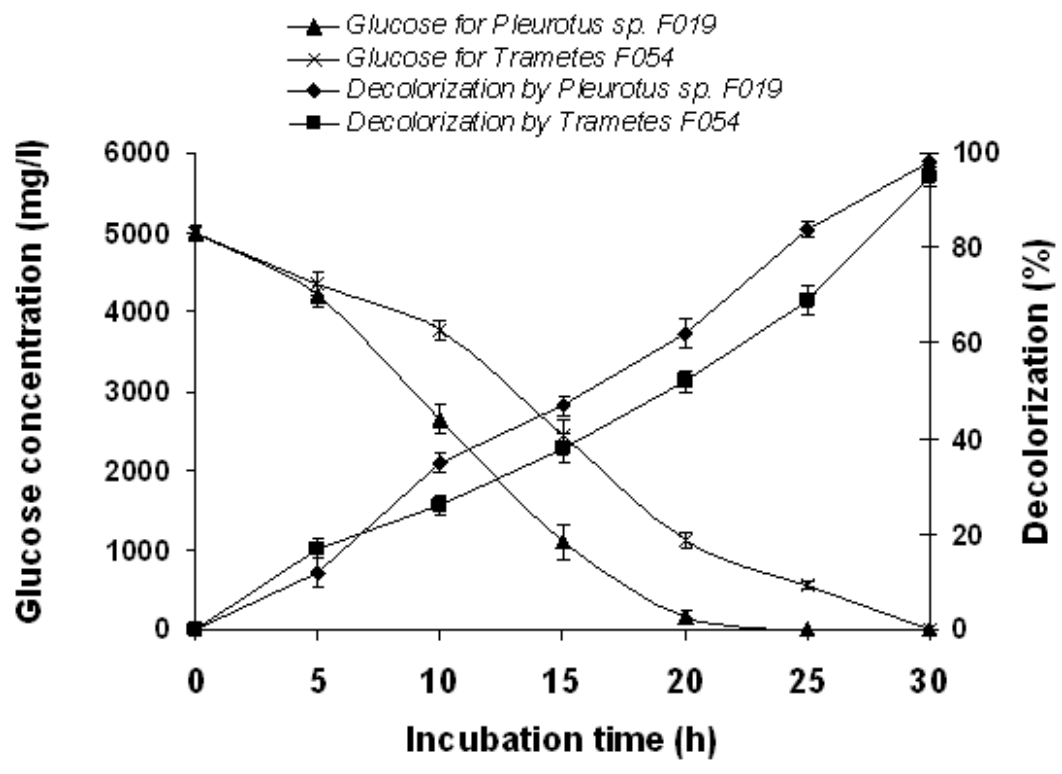

Figure 2 Kinetic relation between glucose utilization and dye decolorization by Pleurotus sp. F019 and Trametes sp. F054. (Data are averages of triplicate experiments).

\subsection{Influence of Glucose Concentration on the Production of Mnp and Decolorization of $\mathbf{R b 5}$}

To better ensure the influence of glucose on the color removal process, the concentration of glucose was intensified to $15 \mathrm{~g} / \mathrm{l}$. The decolorization and enzyme production in these two white rot basidiomycetes were compared with the addition of 5 and $15 \mathrm{~g}$ glucose/l as shown in Figure 3. When the addition of glucose was increased to $15 \mathrm{~g} / \mathrm{l}$, complete decolorization (100\%) was performed by Pleurotus sp. F019 and Trametes sp. F054 within 20 and 25 h, respectively, which was frequently faster than that at the addition of $5 \mathrm{~g}$ glucose/l. No slow phase was notice in the color removal process under higher glucose concentration. However, parallel results were obtained for the relation of $\mathrm{MnP}$ 


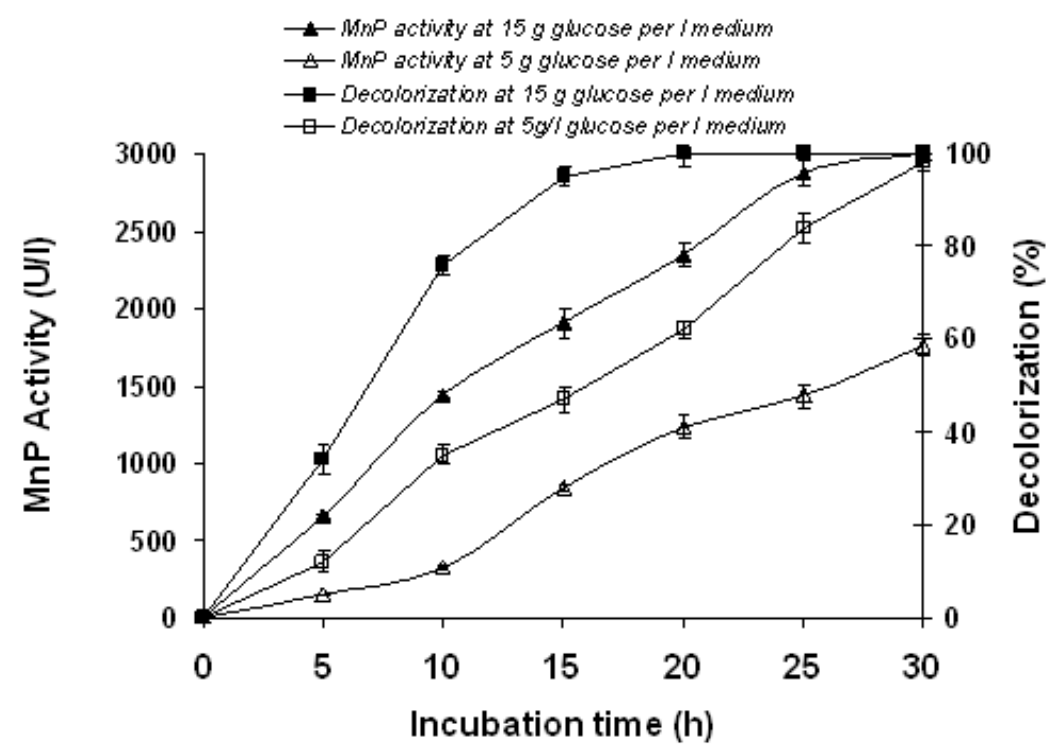

$\mathbf{A}$

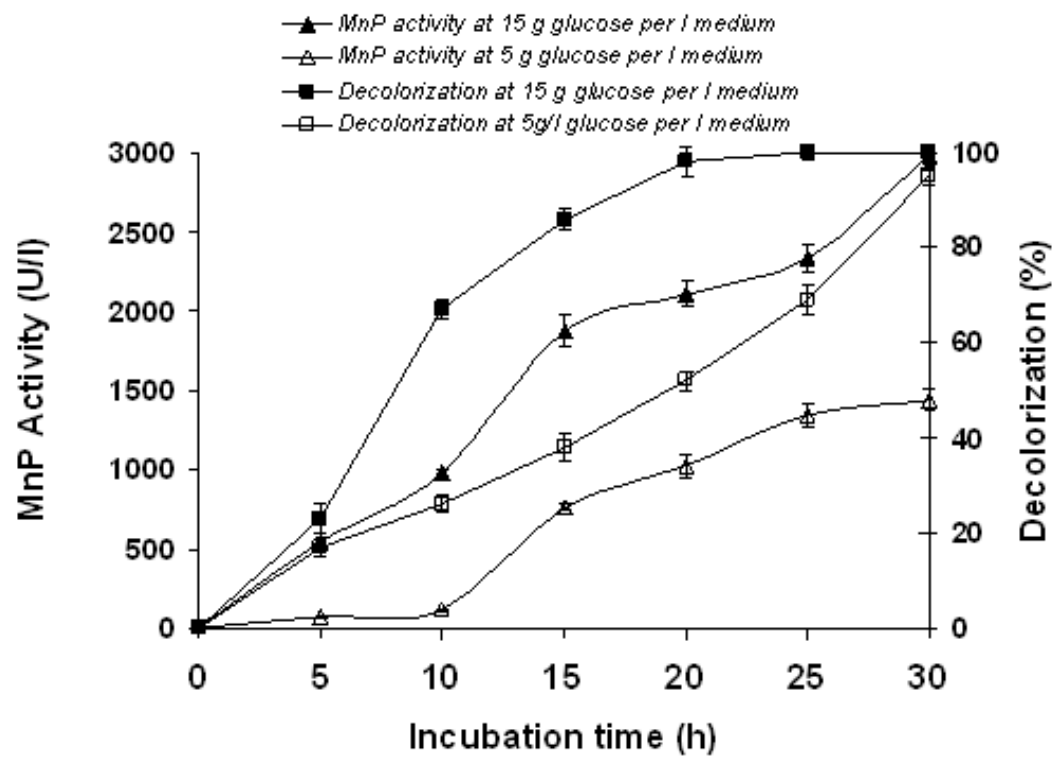

B

Figure 3 Comparison of decolorization and $\mathrm{MnP}$ activities by fungi under different concentrations of glucose: Pleurotus sp. F019 (A) and Trametes sp. F054 (B). (Data are averages of triplicate experiments). 
activity and glucose concentration. The $\mathrm{MnP}$ activities at $15 \mathrm{~g}$ glucose/ $\mathrm{l}$ were about 2-9 fold of those at $5 \mathrm{~g}$ glucose/ $\mathrm{l}$ in these two fungi. However, it is inconvenience to clarify how the fungi cells decolorize $200 \mathrm{mg}$ dye/l in few enzyme activity conditions. In addition, there should be other enzymes responsible for RB5 decolorization by Pleurotus sp. F019 and Trametes sp. F054.

Other studies showed that biodegradation of aromatic hydrocarbon could be performed either by extraceluler ligninolytic enzymes system such as MnP, lignin peroxides $(\mathrm{LiP})$ and laccase or by the oxygenase produced by basidiomycetes [13]. On the other hand, the observation of 1,2- and 2,3dioxygenase suggested that there are a few activities of these enzyme in Pleurotus sp. F019 and Trametes sp. F054 cells at either presence or absence of dye in the culture. The detail mechanism of decolorization by Pleurotus sp. F019 and Trametes sp. F054 requires further research. At least, production of $\mathrm{MnP}$ was a kind of response to the presence of dye by these two fungi and should be related with the process of color removal. As our discussion above, the quick decolorization stage by fungi was strongly accompanied with the cell's growth. It also suggested that 1,2- and 2,3-dioxygenase producing in the process of cell growth might be responsible for color removal and glucose might play important roles in this process except as a carbon or energy source for fungi growth.

\subsection{Hydrogen Peroxide Production}

Production of $\mathrm{H}_{2} \mathrm{O}_{2}$ in Pleurotus sp. F019 and Trametes sp. F054 culture was monitored for $30 \mathrm{~h}$ under a condition of $15 \mathrm{~g}$ glucose/l and $200 \mathrm{mg} \mathrm{RB} 5 / \mathrm{l}$ as shown in Figure 4. The maximum concentration of $\mathrm{H}_{2} \mathrm{O}_{2}(0.55 \mathrm{mg} / \mathrm{l}$ and 0.43 $\mathrm{mg} / \mathrm{l}$ ) was detected at $10 \mathrm{~h}$ and quickly dropped at $15 \mathrm{~h}$, which coincided with the trends of glucose exhaustion and dye decolorization in Figure 2. These results are similar with Hofrichter [14] that $\mathrm{H}_{2} \mathrm{O}_{2}$ or other peroxide was required to initiate the reaction when $\mathrm{MnP}$ attacked lignose or phenyl compounds. The other study showed that $\mathrm{H}_{2} \mathrm{O}_{2}$ was usually formed by another enzyme, glucose peroxidase, which was bound on the cell wall when glucose was utilize by fungi as the major carbon source in the culture [11]. Our result is also similar with Hofrichter's that assuming on the mechanism of $\mathrm{MnP}$ catalysis and other results about $\mathrm{H}_{2} \mathrm{O}_{2}$ production [14]. In this step, glucose played two significant functions in the dye color removal: providing a carbon and energy source for basidiomycetes growth and playing as a substrate for the production of $\mathrm{H}_{2} \mathrm{O}_{2}$. 


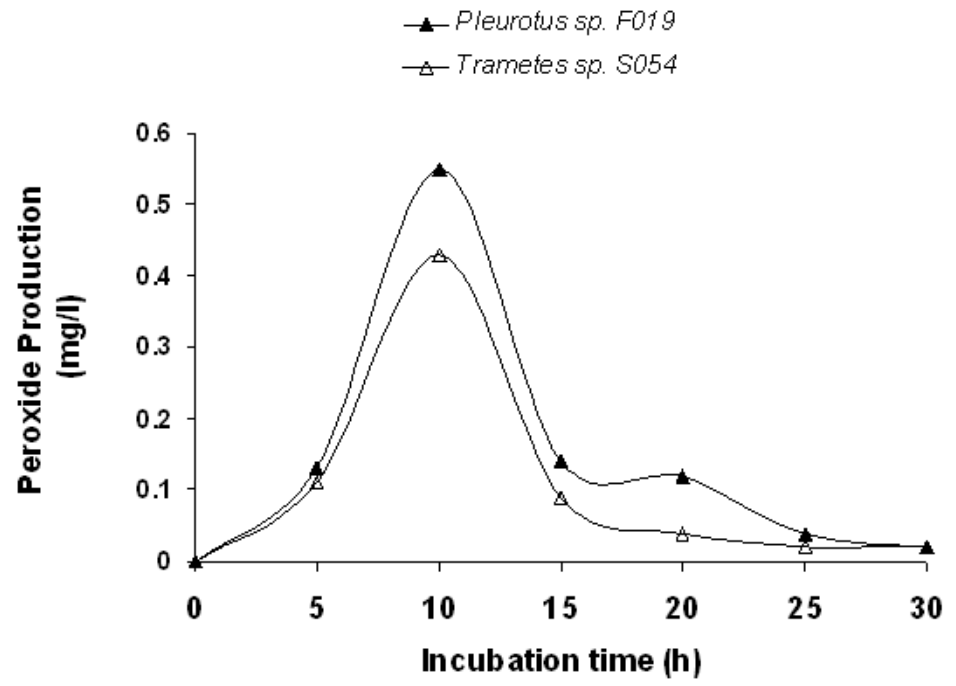

Figure 4 Production of $\mathrm{H}_{2} \mathrm{O}_{2}$ by Pleurotus sp. F019 and Trametes sp. F054.

\section{Conclusions}

The rapid color removal process of RB5 throughout the biodegradation system by two basidiomycetes, Pleurotus sp. F019 and Trametes sp. F054, were highly linked with a carbon source such as glucose, presence in the fungal culture. Increase of addition of glucose concentration from 5 to $15 \mathrm{~g} / \mathrm{l}$ apparently intensified the color removal efficiency correlated with the production of MnP. In the color removal processes, glucose is playing an important role as a source of carbon for fungi growth and a substrate for production of $\mathrm{H}_{2} \mathrm{O}_{2}$. The latter was considered to start the color removal processes and catalytic reaction of $\mathrm{MnP}$. The main role of glucose and $\mathrm{H}_{2} \mathrm{O}_{2}$ in the second cycle of color removal processes tests strongly supported Hofrichter's assumption about the mechanism of $\mathrm{MnP}$ catalysis. The comprehensive characteristic processes of RB5 decolorization by these two basidiomycetes and the crucial enzymes responsible for the decolorization are still required further investigation.

\section{Acknowledgements}

A part of this research was financially supported by an Institutional Research Grant from the Universiti Teknologi Malaysia (Vote No. 77552), which is gratefully acknowledged. 


\section{References}

[1] Aksu, Z. \& Donmez, G., Combined Effects of Molasses Sucrose and Reactive Dye on the Growth and Dye Bioaccumulation Properties of Candida Tropicalis, Process Biochem., 40, 2443-2454, 2005.

[2] Fu, Y. \& Viraraghavan T, Fungal Decolorization of Dye Wastewaters: A Review, Bioresour. Technol., 79, 251-262, 2001.

[3] Lee, Y.H. \& Pavlostathis, S.G., Decolorization and Toxicity of Reactive Anthraquinone Textile Dyes Under Methanogenic Conditions, Water Res., 38, 1838-1852, 2004.

[4] Borchert, M. \& Judy, A.L, Decolorization of Reactive Dyes by the White Rot Fungus Trameters Versicolor in Sequencing Batch Reactors, Biotechnol. Bioeng., 75, 313-321. 2001.

[5] Novotny, C., Svobodova, K., Kasinath, A. \& Erbanova, P., Biodegradation of Synthetic Dyes by Irpex Lacteus under Various Growth Conditions, Int. Biodeter. Biodegr., 54, 215-223, 2004.

[6] Heinzkill, M., Bech, L., Halkier, T., Schneider, P., \& Anke, T., Characterization of Laccases and Peroxidases from Wood Rotting Fungi (Family Coprinaceae), Appl. Environ. Microbiol., 64, 1601-1606, 1998.

[7] Sayan, E. Optimization and Modeling Decolorization And COD Reduction Of Reactive Dye Solution By Ultrasound-Assisted Adsorbtion, Chem. Eng., 119, 175-181, 2006.

[8] Field, J.A., De Jong, E., Feijoo, G. \& De Bont, J.A.M., Screeining for Lignolytic Fungi Applicable to the Biodegradation of Xenobiotics, Trends Biotechnol., 11, 44-49, 1993.

[9] Harris, D.C, Quantitative Chemical Analysis (5th ed.), New York: W.H. Freeman and Company, 1999.

[10] Adosinda, M., Martins, M., Ferreira, I.C., Santos, I.M., Queiroz, M.J. \& Lima, N., Biodegradation of Bioaccessible Textile Azo Dyes by Phanerochaete Crysoporium, J. Biotechnol., 89, 91-98, 2001.

[11] Swamy, J. \& Ramsay, J.A., Effects of glucose and $\mathrm{NH}_{4}^{+}$Concentrations On Sequential Dye Decolorization by Trametes Versicolor, Enzyme Microb. Technol., 25, 278-284, 1999.

[12] Wesenberg, D., Kyriakides, I. \& Agathos, S.N., White Rot Fungi and Their Enzymes for the Treatment of Industrial Dye Effluents, Biotechnol. Adv., 22, 161-187, 2003.

[13] Cerniglia, C.E., Biodegradation of Polycyclic Aromatic Hydrocarbon: A Review, Biodegradation, 3, 351-368, 1992.

[14] Hofrichter, M., Review: Lignin Conversion by Manganese Peroxidase $(M n P)$. Enzyme Microb. Technol., 30, 454-466, 2002. 